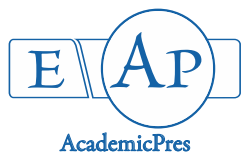

Nayak A and Ghosh S (2020)

Notulae Scientia Biologicae 12(3):592-607

DOI: $10.15835 / \mathrm{nsb} 12310749$

Research Article

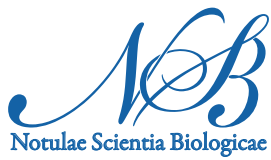

\title{
Moth diversity (Lepidoptera: Heterocera) of Banaras Hindu University, Varanasi, India: a preliminary checklist
}

\author{
Ananya NAYAK ${ }^{1 *}$, Sohini GHOSH ${ }^{2}$ \\ ${ }^{1}$ Bankura Sammilani College, Department of Zoology, Kenduadihi 722102, Bankura, West Bengal, \\ India; ananya001@gmail.com (*corresponding author) \\ ${ }_{2}^{2}$ Banaras Hindu University, Department of Zoology, Varanasi 221005, Uttar Pradesh, India; sohinighosh111@gmail.com
}

\begin{abstract}
A study was conducted at the Banaras Hindu University (BHU) campus of Varanasi, Uttar Pradesh, India to assess the moth fauna of the area. A preliminary checklist was compiled as a base-line contribution to the status of the Lepidoptera diversity of the campus. The campus was surveyed from January to December 2019 and moths were recorded through 83-night surveys and a large number of opportunistic visits in 18 different sites of the campus. The study has recorded a total of 1248 individual moths belonging to 99 morphospecies, 84 genera, and 11 families across different parts of the study area. The most species rich family was Erebidae with 35 species under 30 genera followed by Crambidae ( 33 species; 28 genera), Geometridae (15 species; 11 genera), Noctuidae (seven species; six genera), and others. However, family-wise abundance data indicated that Crambidae (38.70\%) was the most abundant family having highest proportion of moths recorded followed by Erebidae (34.85\%), Geometridae (10.73\%), Noctuidae (6.81\%) and others. This illustrated checklist and the results will improve our understanding of Varanasi's biodiversity and can be used for improvement of the campus planning and developing strategies for conservation of moth diversity.
\end{abstract}

Keywords: $\mathrm{BHU}$; checklist; conservation; Erebidae; moth; urbanization; Varanasi

Abbreviations: BHU-Banaras Hindu University; DNA-Deoxyribonucleic acid; LED-Light Emitting Diode; WHO-World Health Organization; VF-Very Frequent; F-Frequent; IF-Infrequent

\section{Introduction}

Moths are conspicuous terrestrial invertebrates, that represent the majority of the insect order Lepidoptera with over 165,000 described species (Regier et al., 2009). Being a prominent element of terrestrial ecosystems, they function as pollinators of flowers, herbivores of crops and wild plants and prey for numerous species of rodents, birds, and bats (Regier et al., 2009; Bates et al., 2014). Many moth species are nocturnal plant-feeding insects and are almost entirely associated with angiospermous plants that largely depend on animal-assisted pollination (Wahlberg et al., 2013). These polyphyletic groups of insects represent more than $90 \%$ of all lepidopterans of the earth and a large number of moth species are still waiting to be discovered and named, mostly from the tropical regions of the world (Heppner, 2008). These ectothermic animals occupy a wide range of habitats around the world and are sensitive to environmental pressures. Therefore, monitoring 
the changes in the patterns of moth distribution and abundance in an area can be used as potent ecological indicators for the conservation of biodiversity (Dennis et al., 2019).

However, recent reports suggest that moth diversity and abundance around the world has declined significantly in the past few decades (Hallmann et al., 2020). Several factors can be attributed to the worldwide decline in moth population including habitat loss, degradation and fragmentation, agricultural intensification, changes in woodland management, urbanization, chemical pollution, artificial light at night and climate (Dennis et al., 2019). A number of plant species depend exclusively on one or a small number of moth species for pollination and a decline in those moth population and their diversity might lead to a negative impact in the plant communities they pollinate (Young et al., 2017).

India exhibits a very rich moth assemblage with nearly 10,000 species (Smetacek, 2013). Several studies have explored the moth diversity from different states of north India. However, different areas of Himalaya have undoubtedly received more attention than anywhere else because of its extremely rich biodiversity (Hampson, 1892, 1894, 1895, 1896; Smetacek, 2008; Sanyal et al., 2011; Sondhi and Sondhi, 2016; Sanyal et al., 2017). Most of these studies have been made in the states of Uttarakhand and Himachal Pradesh. To date, no comparable studies on moth diversity have been conducted in Varanasi and other parts of the Uttar Pradesh state of India.

In this study, we investigated the moth diversity in the Banaras Hindu University (BHU) campus of Varanasi, Uttar Pradesh, India. Although some studies (Verma et al., 2007) have reported the floral diversity of the university campus, the status of the Lepidoptera diversity of the vast land still remains unknown. A preliminary checklist was generated from the results of the survey for one year. Here we report for the first time, the occurrence of 99 morphospecies of moths from the study area.

\section{Materials and Methods}

\section{Studyarea}

The study was conducted in the campus area of BHU, the largest residential university in Asia, located in Varanasi city of Uttar Pradesh, India (Figure 1a). The University is an urban campus covering an area of approximately 1,300 acres $\left(5.3 \mathrm{~km}^{2}\right)$, which is about $5 \mathrm{~km}$ south of Varanasi City on the western bank of the river Ganga. The city is located between $82^{\circ} 39^{\prime}$ and $83^{\circ} 11^{\prime} \mathrm{E}$ longitude and between $25^{\circ} 10^{\prime}$ and $25^{\circ} 34^{\prime} \mathrm{N}$ latitude. The climate is a humid subtropical climate characterized by dry winters with temperatures between 3 and $18^{\circ} \mathrm{C}$ and summers with a constant rainfall with a mean temperature of nearly $22^{\circ} \mathrm{C}$ (Nistor et al., 2020). The soils in the study area have been described as alluvial, well-drained, pale brown, silty loam and inceptisol with moderately fertility (Verma et al., 2015). Although representing a very small part of the Varanasi city (4.24\%), BHU campus exhibits an enormous diversity of habitats including garden, lake, agricultural land, grassland, bushes having a large number of trees, shrubs, herbs and climbers (Figure 2). The campus gardens and streets are filled with a wide variety of vascular and medicinal plant species like Azadirachta indica, Dalbergia sissoo, Madhuca longifolia, Mangifera indica, Pterygota alata, Tamarindus indica, Tectona grandis, Ziziphus glaberrima etc (Verma et al., 2007; Verma et al., 2015).

\section{Moth surveys and identification}

The above-mentioned areas of the campus were surveyed from January to December 2019. Moths were recorded through light trapping and frequent opportunistic visits to light sources of several hostels, departments and streets of the campus at night. Most of the moths were recorded from the light traps created by mounting a high power (23-Watt) LED lamp in front of a white house wall located at different floors of multi-storey buildings. In addition, a large number of moths were also documented from the hostel premises and street light towers equipped with high power sodium (250-Watt) and mercury vapour lamps (150-180Watt) as well as LED lamps. 

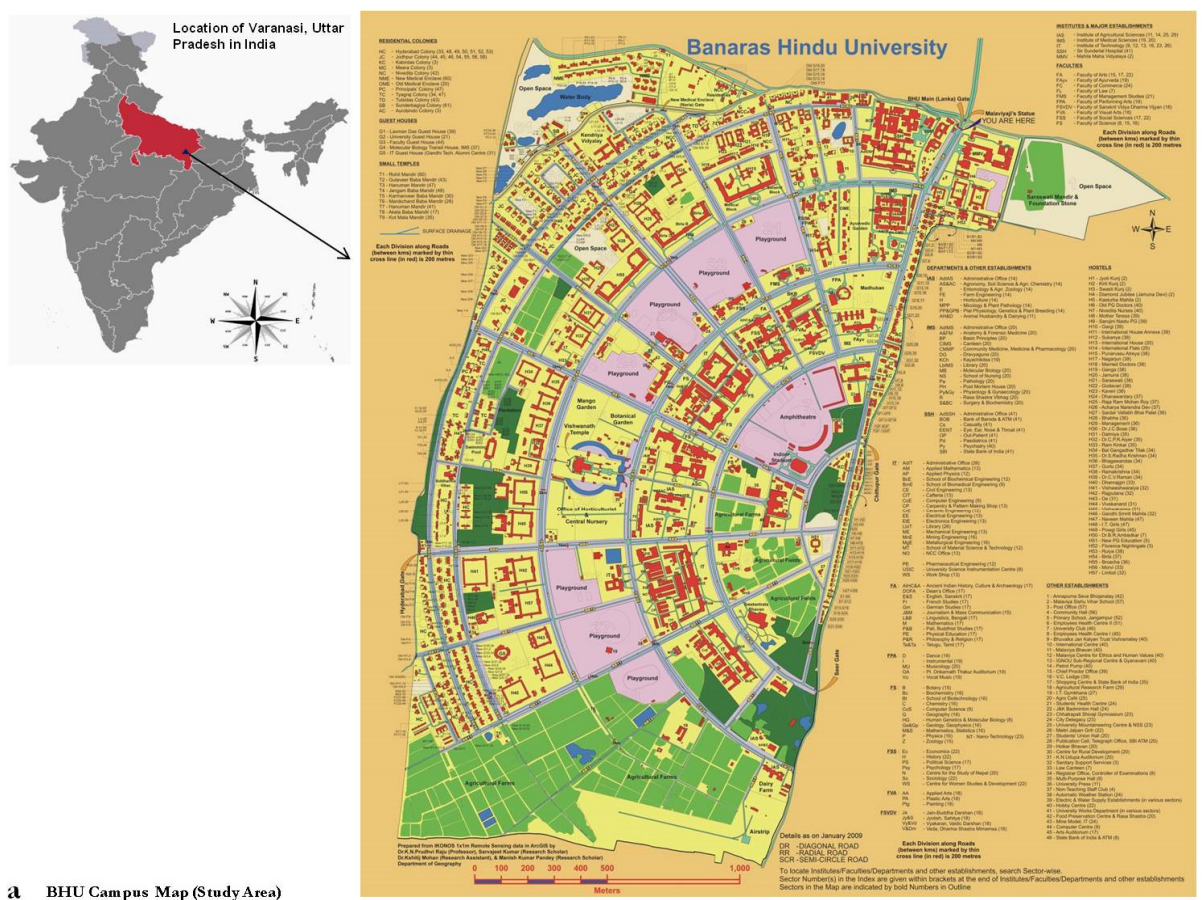

a BHU Campus Map (Study Area)

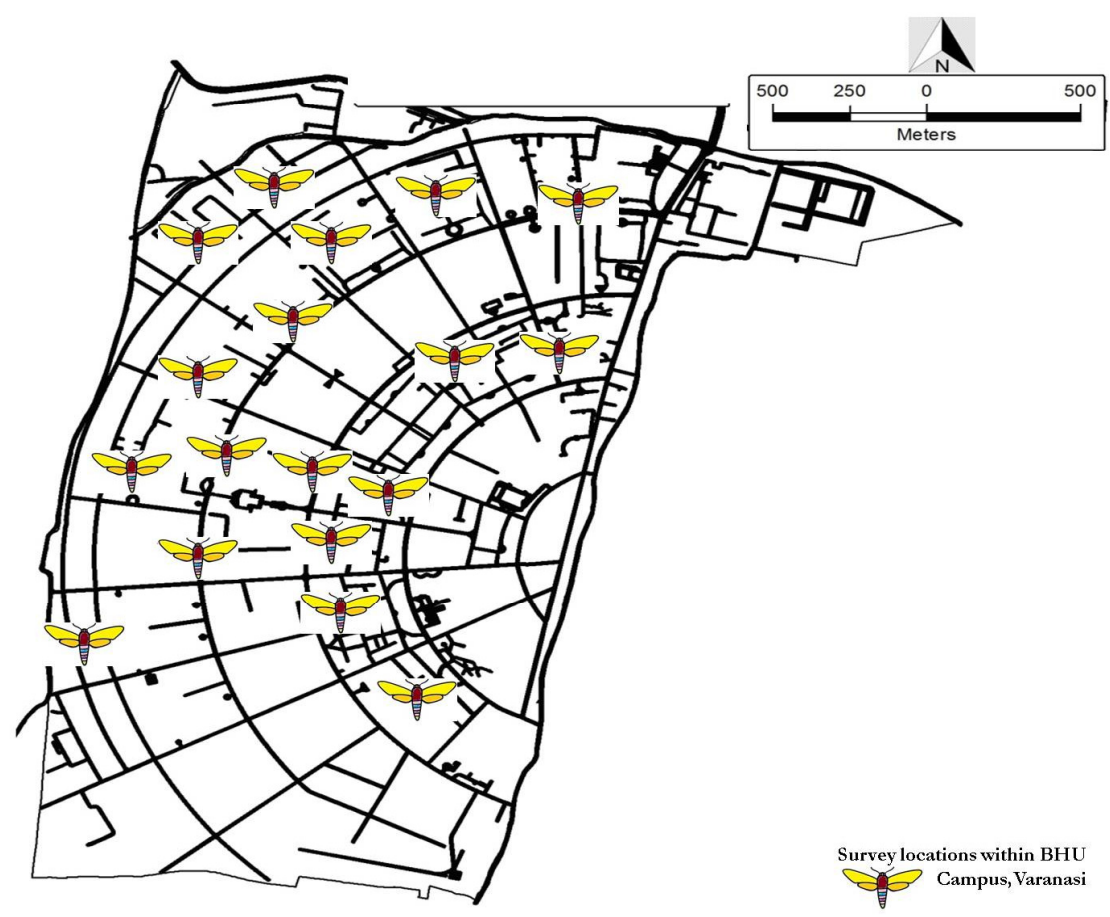

b

Figure 1. a. Map of BHU campus in Varanasi, Uttar Pradesh, India (Map data: India from Wikipedia; Campus map from the university website). b. Survey locations within BHU campus (Map data: Campus map from Raju et al., 2015) 

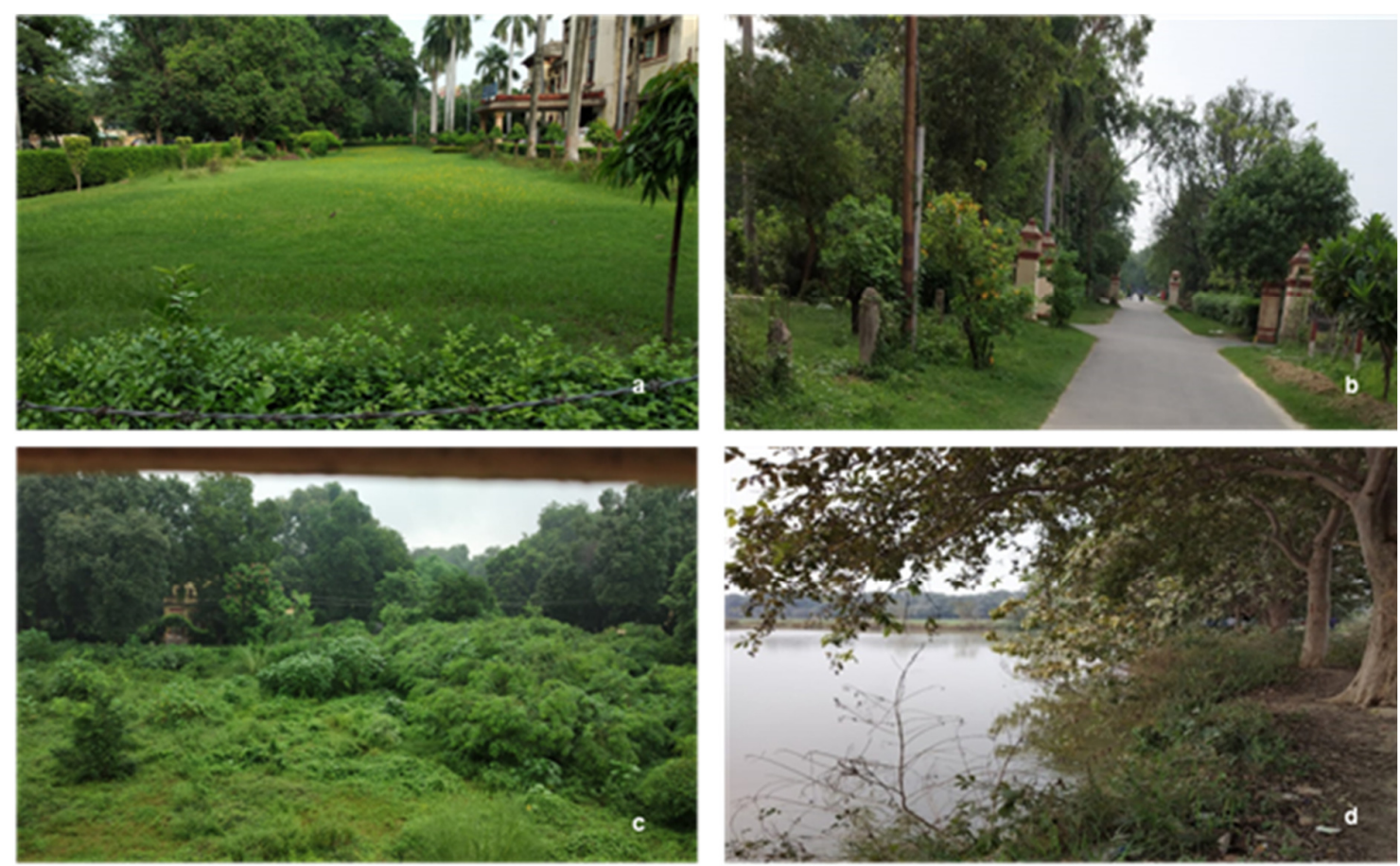

Figure 2. Different types of habitats found within the study area of BHU, Varanasi campus. a. The lawn in front of department of Zoology; b. A street in the university campus; c. Vegetation around the hostel area $\& \mathrm{~d}$. A pond of Institute of Agricultural Sciences

A total of 83 nocturnal surveys and a large number of opportunistic visits were done over a period of one year in 18 different sites of the campus including seven hostels, 10 academic departments and within the premises of Shri Kashi Vishwanath Temple of BHU (Figure 1b). The maximum number of surveys (47) was carried out during the period from August to November. The remaining 21 surveys were conducted from April to July and 15 from December to March. The majority of the surveys were done in the departments, hostels, temple premises, streets and the surrounding areas whereas gardens, lakes and other parts of the campus were some of the least visited places during the diurnal survey. In all the sampling sites moths were recorded from 19.00h to 22:00h except one student residential area where most of the surveys were conducted up to 1 to 2 am. Moth counts were recorded and photographed using a smartphone camera (Xiaomi Redmi Note 5 Pro) to support further identification. Some of the moths were also recorded and photographed during daylight hours. The moth photographs were identified based on physical features with the help of available literatures including Hampson (1892-1896), Bell and Scott (1937), Holloway (1987, 1999, 2005), Schintlmeister and Pinratana (2007), Kononenko and Pinratana (2013) and Kirti and Singh (2015). The classification system used in the present study was adapted from the work of van Nieukerken et al. (2011). In addition, a number of web resources including www.jpmoths.org; Moths of India (http://www.mothsofindia.org/; Sondhi et al., 2020), https://www.flickr.com/groups/mothsofindia/ and iNaturalist (https://www.inaturalist.org) were used for the purpose of identification. All the graphs were generated using Microsoft Office Excel, 2010. None of the species was captured or killed during the entire period of the study. 


\section{Results}

The present study has documented a total of 1248 individual moths belonging to 99 morphospecies, 84 genera, 11 families across different parts of the study area (Table 1, Plates 1-4). Among these 81 moth species were identified to species level and another 18 to generic level. The most species rich family was Erebidae with 35 species under 30 genera followed by Crambidae ( 33 species; 28 genera), Geometridae ( 15 species; 11 genera), Noctuidae (seven species; six genera), and others (Figure 3, Table 2).

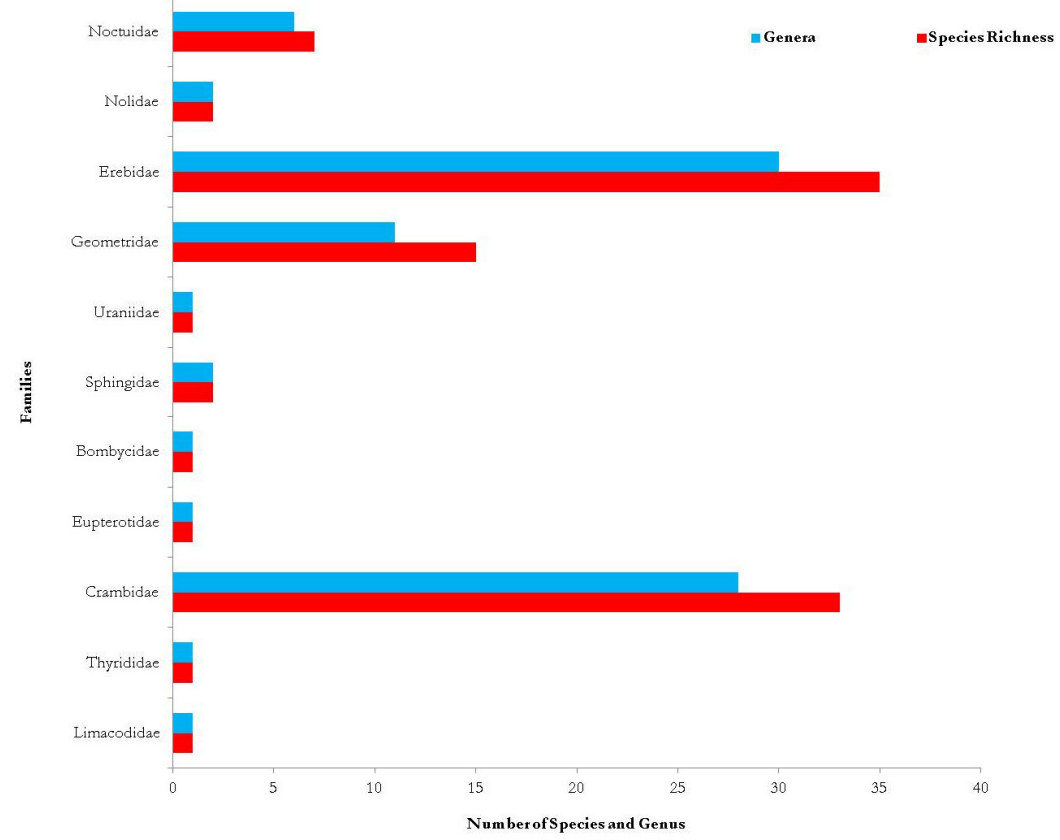

Figure 3. Family wise patterns of moth species richness and number of genera recorded in different habitats of BHU, Varanasi campus

Table 1. Preliminary checklist of moth fauna recorded during the study Status: VF-very frequent (>20\% specimens recorded); F-frequent (10-20\% specimens recorded) and IF-infrequent ( $<10 \%$ specimens recorded)

\begin{tabular}{|c|c|c|c|c|c|}
\hline Sl. No & Family & Subfamily & Species & Author, Year & Status \\
\hline 1 & Limacodidae & Chrysopolominae & Altha subnotata & (Walker, 1865) & VF \\
\hline 2 & Thyrididae & Striglininae & Banisia myrsusalis & (Walker, 1859) & IF \\
\hline 3 & Crambidae & Acentropinae & Elophila sp. & & F \\
\hline 4 & Crambidae & Acentropinae & Parapoynx fluctuosalis & (Zeller, 1852) & F \\
\hline 5 & Crambidae & Acentropinae & Parapoynx diminutalis & Snellen, 1880 & IF \\
\hline 6 & Crambidae & Pyraustinae & Orphanostigma abruptalis & (Walker, 1859) & VF \\
\hline 7 & Crambidae & Pyraustinae & Ostrinia sp. & & F \\
\hline 8 & Crambidae & Pyraustinae & Pardomima distortana & (Strand, 1913) & IF \\
\hline 9 & Crambidae & Pyraustinae & Pyrausta phoenicealis & (Hübner, 1818) & IF \\
\hline 10 & Crambidae & Schoenobiinae & Scirpophaga incertulas & (Walker, 1863) & VF \\
\hline 11 & Crambidae & Spilomelinae & Agrotera posticalis & Wileman, 1911 & IF \\
\hline 12 & Crambidae & Spilomelinae & Antigastra catalaunalis & (Duponchel, 1833) & IF \\
\hline 13 & Crambidae & Spilomelinae & Botyodes diniasalis & (Walker, 1859) & VF \\
\hline 14 & Crambidae & Spilomelinae & Botyodes asialis & Guenée, 1854 & VF \\
\hline 15 & Crambidae & Spilomelinae & Cirrhochrista brizoalis & (Walker, 1859) & F \\
\hline 16 & Crambidae & Spilomelinae & Cnaphalocrocis medinalis & (Guenée, 1854) & VF \\
\hline
\end{tabular}


Nayak A and Ghosh S (2020). Not Sci Biol 12(3):592-607

\begin{tabular}{|c|c|c|c|c|c|}
\hline 17 & Crambidae & Spilomelinae & Cnaphalocrocis bilinealis & (Hampson, 1891) & IF \\
\hline 18 & Crambidae & Spilomelinae & Conogethes punctiferalis & (Guenée, 1854) & $\mathrm{F}$ \\
\hline 19 & Crambidae & Spilomelinae & Diaphania indica & (Saunders, 1851) & $\mathrm{VF}$ \\
\hline 20 & Crambidae & Spilomelinae & Eurrhyparodes bracteolalis & (Zeller, 1852) & IF \\
\hline 21 & Crambidae & Spilomelinae & Glyphodes bicolor & (Swainson, [1821]) & VF \\
\hline 22 & Crambidae & Spilomelinae & Glyphodes actorionalis & (Walker, 1859) & VF \\
\hline 23 & Crambidae & Spilomelinae & Haritalodes derogata & (Fabricius, 1775) & $\mathrm{VF}$ \\
\hline 24 & Crambidae & Spilomelinae & $\begin{array}{c}\text { Herpetogramma } \\
\text { licarsisalis }\end{array}$ & (Walker, 1859) & $\mathrm{VF}$ \\
\hline 25 & Crambidae & Spilomelinae & Hodebertia testalis & (Fabricius, 1794) & IF \\
\hline 26 & Crambidae & Spilomelinae & Maruca vitrata & (Fabricius, 1787) & $\mathrm{VF}$ \\
\hline 27 & Crambidae & Spilomelinae & Metoeca foedalis & (Guenée, 1854) & $\mathrm{F}$ \\
\hline 28 & Crambidae & Spilomelinae & Nausinoe pueritia & (Cramer, [1780]) & $\mathrm{F}$ \\
\hline 29 & Crambidae & Spilomelinae & Omiodes indicata & (Fabricius, 1775) & VF \\
\hline 30 & Crambidae & Spilomelinae & Omiodes diemenalis & (Guenée, 1854) & $\mathrm{VF}$ \\
\hline 31 & Crambidae & Spilomelinae & Parotis cf. marginata & (Hampson, 1893) & $\mathrm{VF}$ \\
\hline 32 & Crambidae & Spilomelinae & Pygospila tyres & (Cramer, 1780) & $\mathrm{VF}$ \\
\hline 33 & Crambidae & Spilomelinae & Sameodes cancellalis & (Zeller, 1852) & $\mathrm{VF}$ \\
\hline 34 & Crambidae & Spilomelinae & Spoladea recurvalis & Fabricius, 1775 & VF \\
\hline 35 & Crambidae & Spilomelinae & Synclera traducalis & (Zeller, 1852) & IF \\
\hline 36 & Eupterotidae & Eupteroptinae & Eupterote bifasciata & Kishida, 1994 & VF \\
\hline 37 & Bombycidae & Bombycinae & Trilocha varians & (Walker, 1855) & $\mathrm{VF}$ \\
\hline 38 & Sphingidae & Macroglossinae & Hippotion cf. rosetta & (Swinhoe, 1892) & IF \\
\hline 39 & Sphingidae & Macroglossinae & Theretra clotho & (Drury, 1773) & IF \\
\hline 40 & Uraniidae & Epipleminae & Phazaca theclata & (Guenée, 1857) & IF \\
\hline 41 & Geometridae & Ennominae & Chiasmia eleonora & (Cramer, 1780) & IF \\
\hline 42 & Geometridae & Ennominae & Chiasmia fidoniata & (Guenée, 1858) & $\mathrm{F}$ \\
\hline 43 & Geometridae & Ennominae & Cleorasp.1 & & IF \\
\hline 44 & Geometridae & Ennominae & Cleora sp.2 & & $\mathrm{F}$ \\
\hline 45 & Geometridae & Ennominae & Gonodontis clelia & (Cramer, [1780]) & IF \\
\hline 46 & Geometridae & Ennominae & Hyperythra lutea & (Stoll, 1781) & VF \\
\hline 47 & Geometridae & Ennominae & Petelia medardaria & $\begin{array}{c}\text { Herrich-Schäffer, } \\
{[1856]}\end{array}$ & IF \\
\hline 48 & Geometridae & Geometrinae & Agathia laetata & (Fabricius, 1794) & IF \\
\hline 49 & Geometridae & Geometrinae & Thalassodes cf. immissaria & Walker, 1861 & IF \\
\hline 50 & Geometridae & Sterrhinae & Chrysocraspeda faganaria & (Guenée, 1858) & $\mathrm{F}$ \\
\hline 51 & Geometridae & Sterrhinae & Antitrygodes cuneilinea & (Walker, 1863) & $\mathrm{F}$ \\
\hline 52 & Geometridae & Sterrhinae & Scopula emissaria & (Walker, 1861) & $\mathrm{F}$ \\
\hline 53 & Geometridae & Sterrhinae & Scopula pulchellata & (Fabricius, 1794) & IF \\
\hline 54 & Geometridae & Sterrhinae & Scopulasp. & & VF \\
\hline 55 & Geometridae & Sterrhinae & Traminda mundissima & (Walker, 1861) & $\mathrm{VF}$ \\
\hline 56 & Erebidae & Aganainae & Asota caricae & (Fabricius, 1775) & $\mathrm{VF}$ \\
\hline 57 & Erebidae & Aganainae & Asota ficus & (Fabricius, 1775) & $\mathrm{VF}$ \\
\hline 58 & Erebidae & Arctiinae & Amata passalis & (Fabricius, 1781) & VF \\
\hline 59 & Erebidae & Arctiinae & Argina astrea & (Drury, 1773) & $\mathrm{VF}$ \\
\hline 60 & Erebidae & Arctiinae & Creatonotos transiens & (Walker, 1855) & $\mathrm{F}$ \\
\hline 61 & Erebidae & Arctiinae & Eilema sp.1 & & $\mathrm{F}$ \\
\hline 62 & Erebidae & Arctiinae & Eilema sp.2 & & $\mathrm{VF}$ \\
\hline 63 & Erebidae & Arctiinae & Pericallia ricini & (Fabricius, 1775) & $\mathrm{VF}$ \\
\hline 64 & Erebidae & Arctiinae & Spilarctiasp. & & IF \\
\hline 65 & Erebidae & Arctiinae & Spilosomasp. & & IF \\
\hline
\end{tabular}


Nayak A and Ghosh S (2020). Not Sci Biol 12(3):592-607

\begin{tabular}{|c|c|c|c|c|c|}
\hline 66 & Erebidae & Boletobiinae & Eublemma dimidialis & (Fabricius, 1794) & IF \\
\hline 67 & Erebidae & Calpinae & Calyptra minuticornis & (Guenée, 1852) & IF \\
\hline 68 & Erebidae & Calpinae & Eudocima materna & (Linnaeus, 1767) & $\mathrm{VF}$ \\
\hline 69 & Erebidae & Calpinae & Eudocima phalonia & (Linnaeus, 1763) & VF \\
\hline 70 & Erebidae & Calpinae & Oraesia emarginata & (Fabricius, 1794) & IF \\
\hline 71 & Erebidae & Calpinae & Rhesalasp. & & IF \\
\hline 72 & Erebidae & Erebinae & Achaea janata & (Linnaeus, 1758) & $\mathrm{F}$ \\
\hline 73 & Erebidae & Erebinae & Artena dotata & (Fabricius, 1794) & $\mathrm{VF}$ \\
\hline 74 & Erebidae & Erebinae & Bastilla angularis & (Boisduval, 1833) & IF \\
\hline 75 & Erebidae & Erebinae & Bastilla arctotaenia & (Guenée, 1852) & VF \\
\hline 76 & Erebidae & Erebinae & Chalciope mygdon & (Cramer, 1777) & IF \\
\hline 77 & Erebidae & Erebinae & Ercheia cyllaria & (Cramer, 1779) & IF \\
\hline 78 & Erebidae & Erebinae & Ericeia inangulata & (Guenée, 1852) & $\mathrm{VF}$ \\
\hline 79 & Erebidae & Erebinae & Mocis frugalis & (Fabricius, 1775) & $\mathrm{VF}$ \\
\hline 80 & Erebidae & Erebinae & Mocis undata & (Fabricius, 1775) & $\mathrm{VF}$ \\
\hline 81 & Erebidae & Erebinae & Spiramacf. retorta & (Clerck, 1764) & $\mathrm{VF}$ \\
\hline 82 & Erebidae & Erebinae & Thyas coronata & (Fabricius, 1775) & IF \\
\hline 83 & Erebidae & Eulepidotinae & Anticarsia irrorata & (Fabricius, 1781) & IF \\
\hline 84 & Erebidae & Herminiinae & Simpliciasp. & & $\mathrm{F}$ \\
\hline 85 & Erebidae & Hypocalinae & Hypocala sp. & & IF \\
\hline 86 & Erebidae & Lymantriinae & Euproctis sp. & & IF \\
\hline 87 & Erebidae & Lymantriinae & Nygmia icilia & (Stoll, [1790]) & $\mathrm{F}$ \\
\hline 88 & Erebidae & Lymantriinae & Orvascasp. & & IF \\
\hline 89 & Erebidae & Lymantriinae & Somenasp. & & IF \\
\hline 90 & Erebidae & Scoliopteryginae & Anomis flava & (Fabricius, 1775) & IF \\
\hline 91 & Nolidae & Nolinae & Nola analis & $\begin{array}{c}\text { (Wileman \& West, } \\
1928)\end{array}$ & IF \\
\hline 92 & Nolidae & Nolinae & Selepa celtis & Moore, [1860] & VF \\
\hline 93 & Noctuidae & Condicinae & Condicasp. & & IF \\
\hline 94 & Noctuidae & Heliothinae & Helicoverpasp. & & $\mathrm{F}$ \\
\hline 95 & Noctuidae & Noctuinae & Leucania loreyi & (Duponchel, 1827) & VF \\
\hline 96 & Noctuidae & Noctuinae & Leucaniasp. & & $\mathrm{F}$ \\
\hline 97 & Noctuidae & Noctuinae & Polytela gloriosae & Fabricius, 1781 & IF \\
\hline 98 & Noctuidae & Noctuinae & Spodoptera litura & (Fabricius, 1775) & $\mathrm{VF}$ \\
\hline 99 & Noctuidae & Plusiinae & Ctenoplusia agnata & (Staudinger, 1892) & $\mathrm{VF}$ \\
\hline
\end{tabular}

Table 2. Family wise number of species recorded during the survey

\begin{tabular}{|c|c|c|}
\hline Sl No & Family & Number of Species recorded \\
\hline 1 & Limacodidae & 1 \\
\hline 2 & Thyrididae & 33 \\
\hline 3 & Crambidae & 1 \\
\hline 4 & Eupterotidae & 1 \\
\hline 5 & Bombycidae & 2 \\
\hline 6 & Sphingidae & 1 \\
\hline 7 & Uraniidae & 15 \\
\hline 8 & Geometridae & 35 \\
\hline 9 & Erebidae & 2 \\
\hline 10 & Nolidae & 7 \\
\hline 11 & Noctuidae & 99 \\
\hline
\end{tabular}



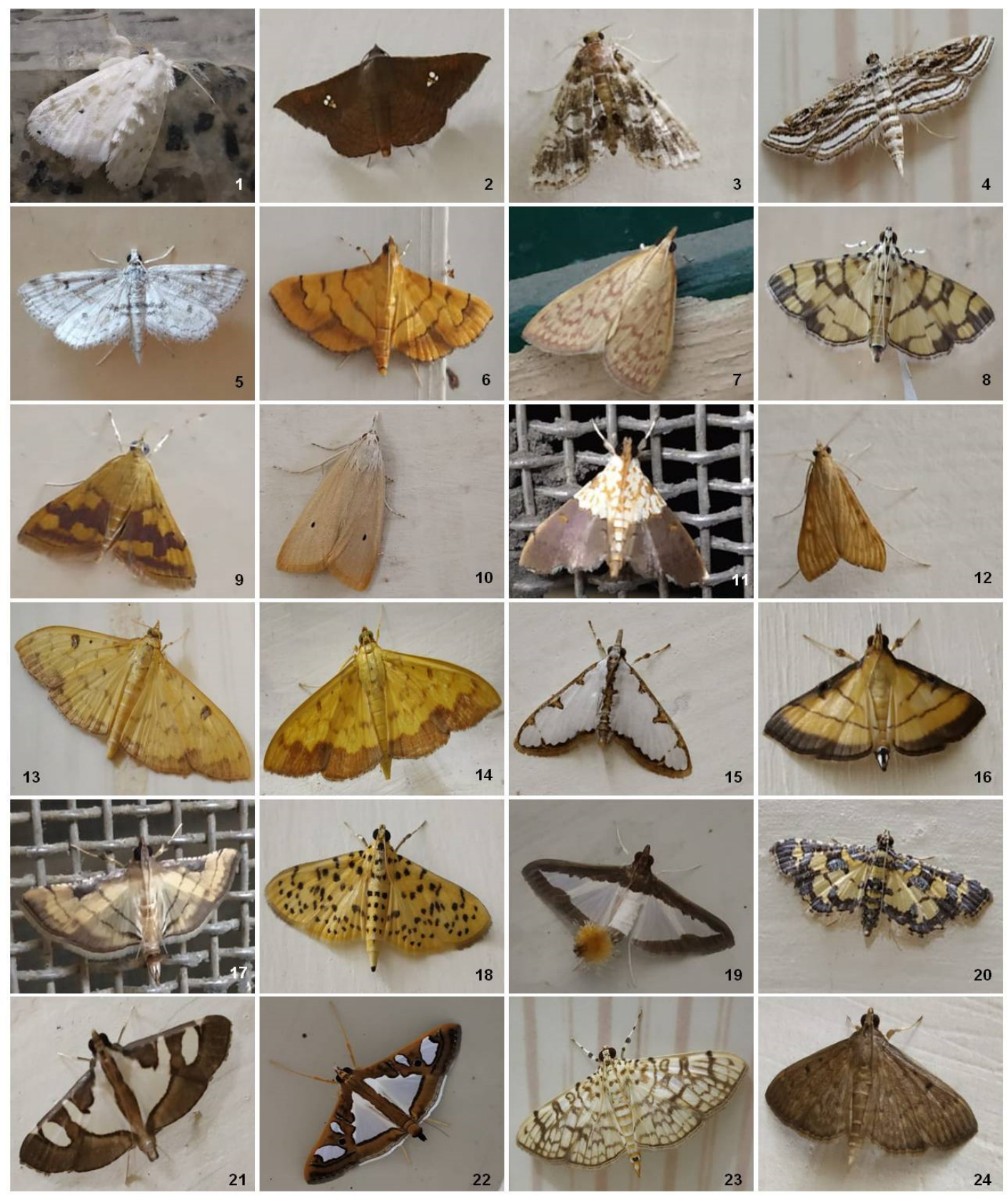

Plate 1. 1-Altha subnotata; 2-Banisia myrsusalis;; 3-Elophila sp;; 4-Parapoynx fluctuosalis; 5-Parapoynx diminutalis; 6-Orphanostigma abruptalis; 7-Ostrinia sp.; 8-Pardomima distortana; 9-Pyrausta phoenicealis; 10-Scirpophaga incertulas; 11-Agrotera posticalis; 12-Antigastra catalaunalis, 13Botyodes diniasalis, 14-Botyodes asialis; 15-Cirrhochrista brizoalis, 16-Cnaphalocrocis medinalis, 17Cnaphalocrocis bilinealis; 18-Conogethes punctiferalis; 19-Diaphania indica; 20-Eurrhyparodes bracteolalis; 21-Glyphodes bicolor, 22-Glyphodes actorionalis; 23-Haritalodes derogata; 24Herpetogramma licarsisalis 

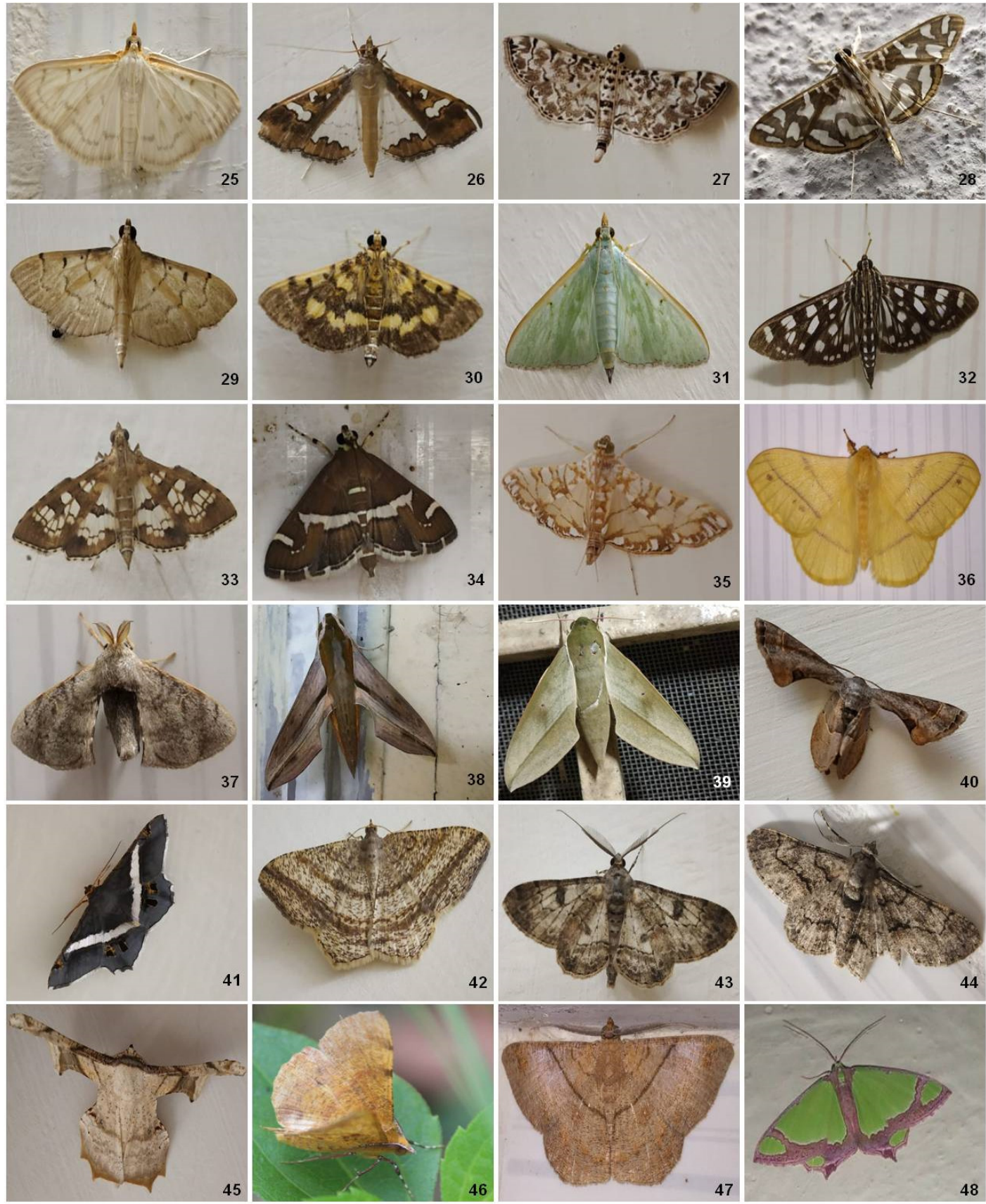

Plate 2. 25-Hodebertia testalis 26-Maruca vitrata; 27-Metoeca foedalis, 28-Nausinoe pueritia; 29Omiodes indicata; 30-Omiodes diemenalis; 31-Parotis cf. marginata; 32-Pygospila tyres; 33-Sameodes cancellalis, 34-Spoladea recurvalis, 35-Synclera traducalis, 36-Eupterote bifasciata; 37-Trilocha varians; 38-Hippotion cf. rosetta; 39-Theretra clotho; 40-Phazaca theclata; 41-Chiasmia eleonora; 42Chiasmia fidoniata; 43-Cleora sp.1; 44-Cleora sp.2; 45-Gonodontis clelia; 46-Hyperythra lutea; 47Petelia medardaria; 48-Agathia laetata 

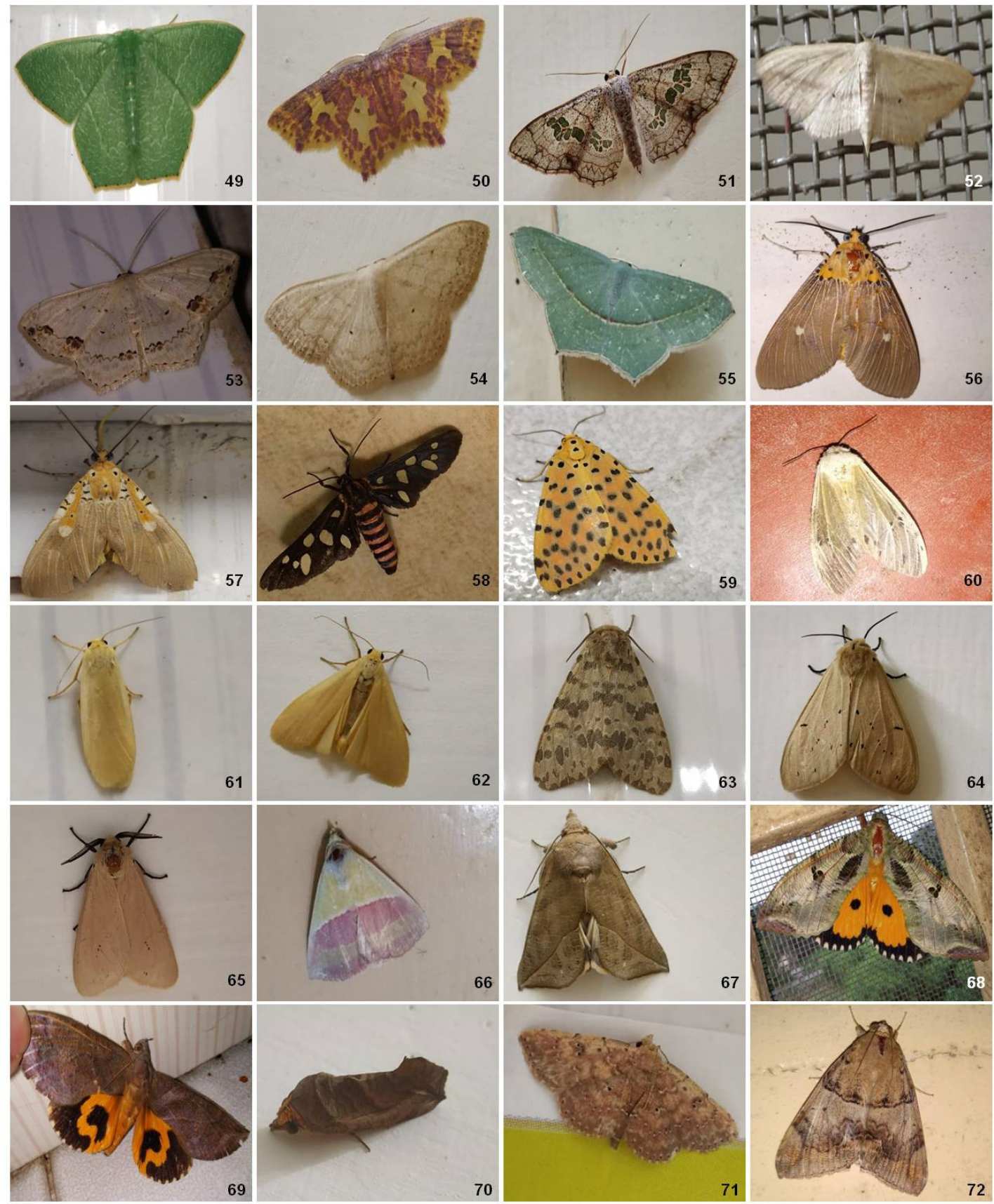

Plate 3. 49- Thalassodes cf. immissaria; 50-Chrysocraspeda faganaria; 51-Antitrygodes cuneilinea; 52Scopula emissaria; 53-Scopula pulchellata; 54-Scopula sp.; 55-Traminda mundissima; 56-Asota caricae, 57-Asota ficus; 58-Amata passalis; 59-Argina astrea; 60-Creatonotos transiens; 61-Eilema sp.1; 62Eilema sp.2; 63-Pericallia ricini; 64-Spilarctia sp.; 65-Spilosoma sp. 66-Eublemma dimidialis; 67Calyptra minuticornis; 68-Eudocima materna; 69-Eudocima phalonia; 70-Oraesia emarginata; 71Rhesala sp.; 72-Achaea janata 

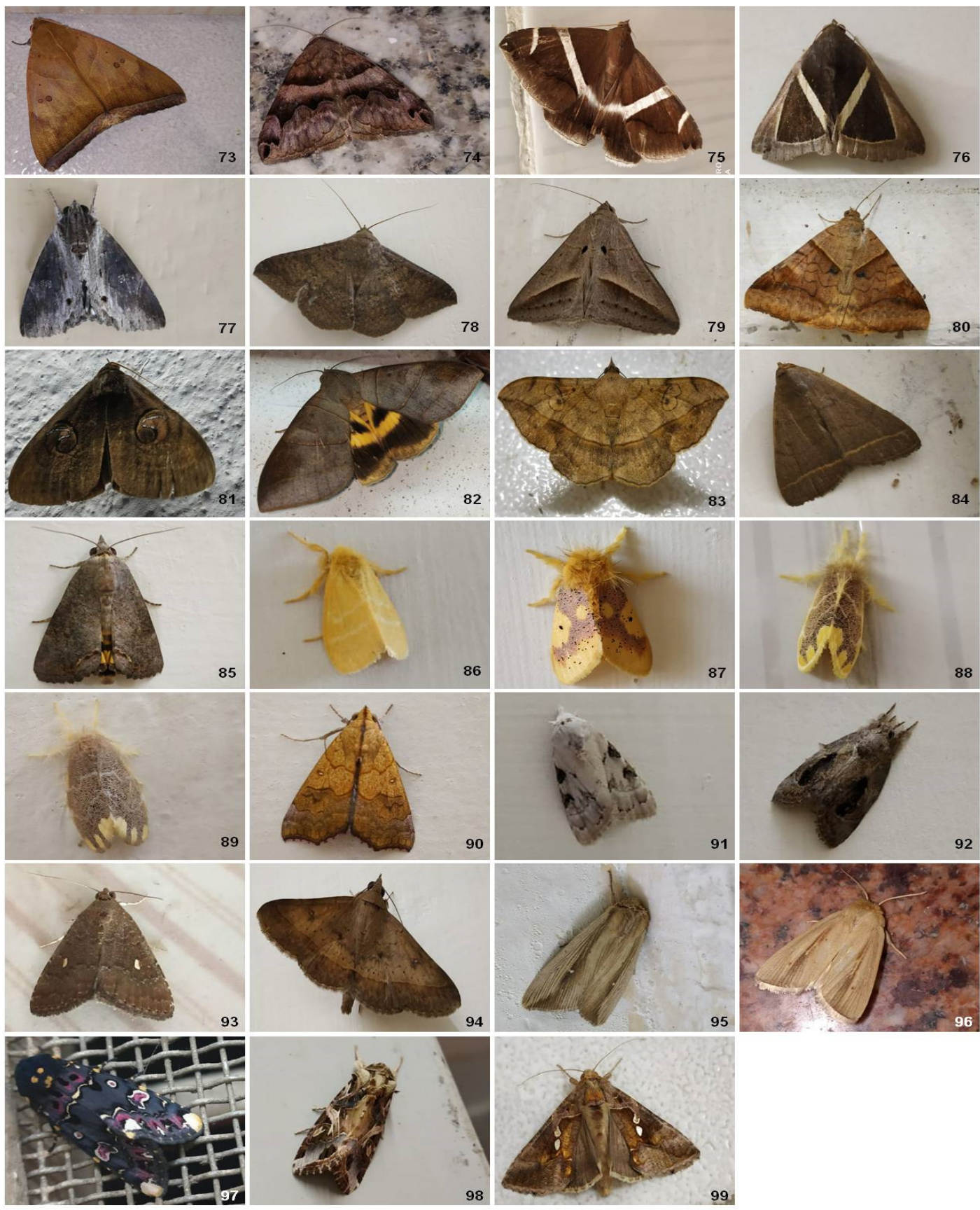

Plate 4. 73-Artena dotata; 74-Bastilla angularis, 75-Bastilla arctotaenia; 76-Chalciope mygdon; 77Ercheia cyllaria; 78-Ericeia inangulata; 79-Mocis frugalis; 80-Mocis undata; 81-Spirama cf. retorta; 82Thyas coronata; 83-Anticarsia irrorata; 84-Simplicia sp.; 85-Hypocala sp.; 86-Euproctis sp.; 87-Nygmia icilia; 88-Orvasca sp.; 89-Somena sp.; 90-Anomis flava; 91-Nola analis; 92-Selepa celtis; 93-Condica sp.; 94-Helicoverpa sp.; 95-Leucania loreyi; 96-Leucania sp.; 97-Polytela gloriosae; 98-Spodoptera litura; 99-Ctenoplusia agnata. 
The rest of the families were represented by a very low number of species. However, family-wise abundance data indicated that Crambidae (38.70\%) was the most abundant family having highest proportion moths recorded followed by Erebidae (34.85\%), Geometridae (10.73\%), Noctuidae (6.81\%) and others. The findings, again, were consistent with prior research that showed the dominance of these moth families in a similar humid subtropical climate like Varanasi (Sondhi and Sondhi, 2016). However, five (Bombycidae, Eupterotidae, Limacodidae, Thyrididae and Uraniidae) of the 11 families showed the least species richness with only one representative species recorded from each of these families. A species accumulation curve was constructed which depicts the cumulative number of observed species as a function of sample efforts (Figure 4a). When a total number of recorded species reached to a value of 99 , the species accumulation curve nearly reached saturation. Based on their frequency of occurrence, all the species were classified into three categories (Table 1).

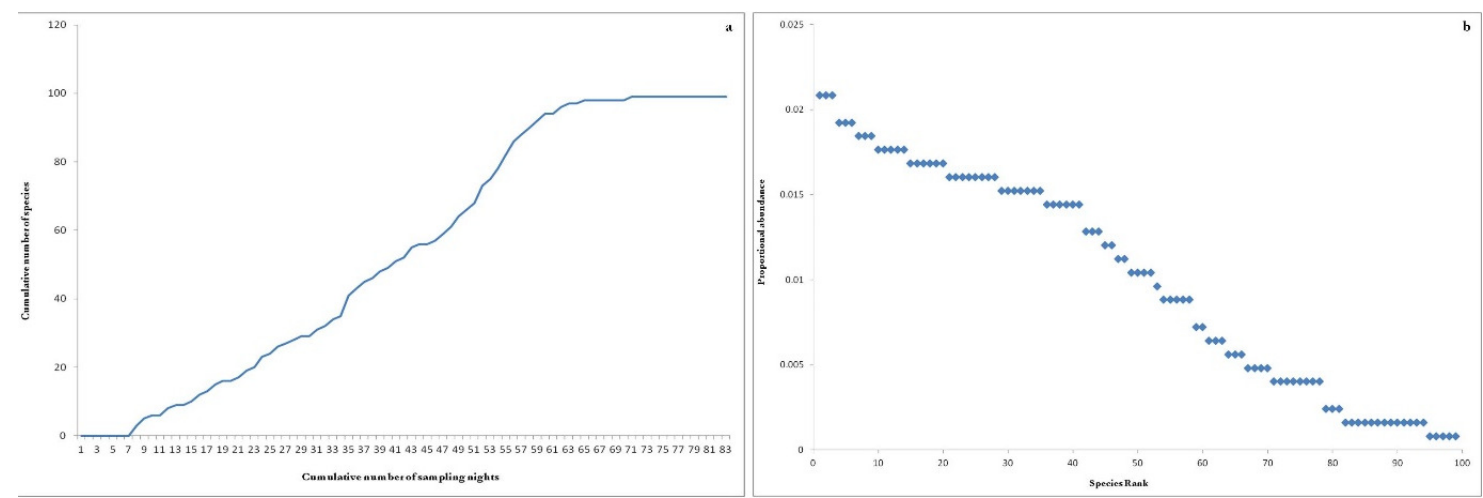

Figure 4. a. Species accumulation curve; $\mathrm{x}$-axis = cumulative number of sampling nights, $\mathrm{y}$-axis = cumulative number of species observed. b. Rank abundance curve displaying relative moth species abundance, for the survey period

The study recorded 41 very frequent, 19 frequent and 39 infrequent species of moths during the survey period. The rank-abundance curve for moths showed that overall, three species are the most abundant in the study area, the Cnaphalocrocis medinalis (Guenée,1854), Spoladea recurvalis (Fabricius, 1775) and Pericallia ricini (Fabricius, 1775) (Figure 4b). The least common members observed were Antigastra catalaunalis (Duponchel, 1833), Bastilla angularis (Boisduval, 1833), Chiasmia eleonora (Cramer, 1780), Ercheia cyllaria (Cramer, 1779) and Condicasp (Figure 4b). The study has also recorded a number of pests of common crops and fruits of the area e.g. Achaea janata (Linnaeus, 1758), Helicoverpa sp., Maruca vitrata (Fabricius, 1787), Ostrinia sp., Spodoptera litura (Fabricius, 1775) and others.

\section{Discussion}

In the present study across different habitats of the campus, we found that members of the two moth families (Crambidae \& Erebidae) were very frequent with a less frequent documentation from Geometridae and Noctuidae. The high abundance of the Crambidae family can be attributed to the presence of a large number of agro-ecosystems and grassy habitats throughout the campus. Further, their larvae show a wide range of adaptations with phytophagous, detritivorous, coprophagous, parasitic habits, and can feed on roots, stems or grasses (Zhu et al., 2018). We assume that the lower species richness of the other seven families especially the families with singleton captures could have been improved by repeated sampling in a systematic approach.

Moths constitute an important part of the biodiversity of an area and play a major role in maintaining a healthy environment and ecological balance of the area. Over the last few decades, Varanasi has faced rapid urbanization by expanding in all directions and its population has increased at an unprecedented rate (Kumar 
et al., 2010). Most of the unplanned urban areas in the city have lost their natural wetlands and green space. The unprecedented rate of urbanization and associated environmental processes pose greatest threats to the native biodiversity and support only highly depauperate insect faunas that can withstand the substantial structural and biotic changes (New, 2018). Previous studies suggest that urban areas exhibit a substantial decline in insect species richness, particularly of Diptera and Lepidoptera in comparison to their surrounding rural areas (Clark et al., 2007; Theodorou et al., 2020). Other works have demonstrated that Lepidoptera assemblage in urbanized locations are negatively affected by urbanization and remains in a disturbed state with a reduced population size and species richness (McGeoch and Chown, 1997; Bates et al., 2014)

Universities are centres for higher education that have a unique potential for adopting a biophilic design in their campus areas and can help for a closer reconnection of urban residents to the biosphere (Colding and Barthel, 2017). Many urban universities all over the world have started to develop their own action plan on monitoring, management, and conservation of biodiversity in their campus area. During the last two decades BHU has taken a number of initiatives to protect and preserve the biodiversity of its south campus $(2,700$ acres), located in Barkachha of Mirzapur district. A biodiversity park at its South Campus in a piece of 500 acres of land has been established by the Centre for Environmental Science \& Technology for the conservation of biodiversity. However, due to space constraints, the university could not take such steps in its main campus at Varanasi.

The study area has a number of disturbances to the moth population and other parts of the campus biodiversity. Anthropogenic disturbances, including collection of medicinal plants, fuel wood and fodder, trampling, scraping and grazing have been reported from the campus area (Verma et al., 2007; Verma et al., 2015). These activities might affect some moth and other invertebrate species that depend on these key structural habitat attributes for their survival. Varanasi has been described as one of the most polluted regional cities on the earth in terms of air quality with air pollutant level 12 times higher than the WHO annual guideline (Mukherjee and Agrawal, 2018). A recent study has reported that besides its negative impacts on human health and local economies, direct or indirect haze exposure can lead to a significant increase in the caterpillar mortality and altered larval development time and pupal weight in a butterfly species (Tan et al., 2018). Another major concern for the moth life is that, many natural or semi-natural habitats in the campus area are experiencing artificial light pollution by inappropriate or excessive use of artificial light which will have some negative impacts on Lepidoptera as well as other nocturnal insect communities of the area. Studies have shown that night time illumination of cities especially the artificial lights from street lamps could potentially turn urban areas into ecological traps for moths (Plummer et al., 2016). Recent studies have reported that artificial light pollution may cause spatial and temporal disorientation, desynchronization of biorhythms and desensitization of the visual systems affecting the physiology and behaviour of various organisms including nocturnal pollinators which in turn may affect several associated ecosystem functions and contribute to a decline in their population (van Langevelde et al., 2011; Owens and Lewis, 2018).

The study unavoidably has some limitations. Moths were not recorded by standard light trapping devices using Mercury vapour lamps. All the moth species were identified by morphological characters using digital colour photographs rather using more sophisticated methods like DNA barcoding or analysis of dissected genitalia structures. Despite these limitations, the study still managed to gather a large number of moth species that has not been previously reported from this region.

\section{Conclusions}

The land of BHU campus has remained undisturbed and preserved its biodiversity for more than hundred years since its establishment in 1916. Therefore, the amount of biodiversity observed here can never be seen in other parts of the city. Our data produce a baseline assessment of the current Lepidopteran diversity across the university campus by inventorying a significant number of moth species. In conclusion, we are able 
to present a preliminary checklist of moths from the BHU campus for the first time based on an opportunity sampling method. Future work in a systematic way is needed to elucidate the complete moth assemblages of the campus. Finally, there is still significant scope for improvement of the campus planning by establishing and maintaining green areas and incorporating meaningful conservation measures for protection of biodiversity of this beautiful academic institution.

\section{Authors' Contributions}

AN conceived the study, identified the moths, prepared the tables, plates and figures and wrote and reviewed the manuscript. SG conducted the field work from January to December 2019. Both authors read, discussed and approved the final version of the paper.

Ethical approval (for researches involving animals or humans)

None of the species was captured or killed or subjected to any experimental treatment during the entire period of the study

\section{Acknowledgements}

This research received no specific grant from any funding agency in the public, commercial, or not-forprofit sectors.

\section{Conflict of Interests}

The authors declare that there are no conflicts of interest related to this article.

\section{References}

Bates AJ, Sadler JP, Grundy D, Lowe N, Davis G, Baker D, ...Young H (2014). Garden and landscape-scale correlates of moths of differing conservation status: significant effects of urbanization and habitat diversity. Plos One 9(1):e86925. https://doi.org/10.1371/journal.pone.0086925

Bell TRD, Scott FB (1937). Fauna of British India, including Ceyon and Burma. Taylor and Francis (Volume 5), London. Clark PJ, Reed JM, Chew FS (2007). Effects of urbanization on butterfly species richness, guild structure, and rarity. Urban Ecosystems 10:321-337. https://doi.org/10.1007/s11252-007-0029-4

Colding J, Barthel S (2017). The role of university campuses in reconnecting humans to the biosphere. Sustainability 9(12):2349. https://doi.org/10.3390/su9122349

Dennis EB, Brereton TM, Morgan BJT, Fox R, Shortall CR, Prescott T, Foster S (2019). Trends and indicators for quantifying moth abundance and occupancy in Scotland. Journal of Insect Conservation 23:369-380. https://doi.org/10.1007/s10841-019-00135-z

Hallmann CA, Zeegers T, van Klink R, Vermeulen R, van Wielink P, Spijkers H, ... Jongejans E (2020). Declining abundance of beetles, moths and caddisflies in the Netherlands. Insect Conservation and Diversity 13:127-139. https://doi.org/10.1111/icad.12377

Hampson GF (1892). The Fauna of British India, including Ceylon and Burma. Taylor and Francis (Volume 1), London, pp 527. 
Hampson GF (1894). The Fauna of British India, including Ceylon and Burma. Taylor and Francis (Volume 2), London, pp 609.

Hampson GF (1895). The Fauna of British India, including Ceylon and Burma. Taylor and Francis (Volume 3), London, pp 546.

Hampson GF (1896). The Fauna of British India, including Ceylon and Burma. Taylor and Francis (Volume 4), London, pp 594.

Heppner JB (2008). Moths (Lepidoptera: Heterocera). In: Capinera JL (Ed) Encyclopedia of Entomology. Springer, Dordrecht pp 2491-2494.

Holloway JD (1987). The moths of Borneo (Part 3): Lasiocampidae, Eupterotidae, Bombycidae, Brahmaeidae, Saturniidae, Sphingidae. Southdene Sdn. Bhd., Kuala Lumpur, Malaysia.

Holloway JD (1999). The moths of Borneo (part 5): family Lymantriidae. Malayan Nature Journal 53:1-188.

Holloway JD (2005). The moths of Borneo: family Noctuidae, subfamily catocalinae. Malayan Nature Journal 58(1-4):1529.

Kirti JS, Singh N (2015). Arctiid moths of India. Nature Books (Volume 1), New Delhi, India.

Kononenko VS, Pinratana A (2013). Moth of Thailand Vol. 3, Part 2. Noctuoidea. An illustrated Catalogue of Erebidae, Nolidae, Euteliidae and Noctuidae (Insecta, Lepidoptera) in Thailand. Brothers of St Gabriel in Thailand, Bangkok.

Kumar M, Mukherjee N, Sharma GP, Raghubanshi AS (2010). Land use patterns and urbanization in the holy city of Varanasi, India: a scenario. Environmental Monitoring and Assessment 167(1-4):417-422. https://doi.org/10.1007/s10661-009-1060-0

McGeoch MA, Chown SL (1997). Impact of urbanization on a gall-inhabiting Lepidoptera assemblage: the importance of reserves in urban areas. Biodiversity and Conservation 6:979-993. https://doi.org/10.1023/A:1018315614085

Mukherjee A, Agrawal M (2018). Air pollutant levels are 12 times higher than guidelines in Varanasi, India. Sources and transfer. Environmental Chemistry Letters 16(3):1009-1016. https://doi.org/10.1007/s10311-018-0706-y

New TR (2018). Promoting and developing insect conservation in Australia's urban environments. Austral Entomology 57:182-193. https://doi.org/10.1111/aen.12332

Nistor MM, Rai PK, Dugesar V, Mishra VN, Singh P, Arora A, ... Carebia IA (2020). Climate change effect on water resources in Varanasi district, India. Meteorological Applications 27:e1863. https://doi.org/10.1002/met.1863

Owens A, Lewis SM (2018). The impact of artificial light at night on nocturnal insects: A review and synthesis. Ecology and evolution 8(22):11337-11358. https://doi.org/10.1002/ece3.4557

Plummer KE, Hale JD, O'Callaghan MJ, Sadler JP, Siriwardena GM (2016). Investigating the impact of street lighting changes on garden moth communities. Journal of Urban Ecology 2:1-10. https://doi.org/10.1093/jue/juw004

Raju KNP, Rai PK, Mohan K, Singh S, Srivastava A (2015). Master Plan of a Campus: Challenges and a Way Through Remote Sensing and GIS. Asian Journal of Geoinformatics 15:1-10.

Regier JC, Zwick A, Cummings MP, Kawahara AY, Cho S, Weller S, ... Mitter C (2009). Toward reconstructing the evolution of advanced moths and butterflies (Lepidoptera: Ditrysia): an initial molecular study. BMC Evolutionary Biology 9(1):280. https://doi.org/10.1186/1471-2148-9-280

Sanyal AK, Dey P, Uniyal V, Chandra K, Raha A (2017). Geometridae Stephens, 1829 from different altitudes in Western Himalayan Protected Areas of, India (Lepidoptera: Geometridae). SHILAP Revista de Lepidopterología 45:143-163.

Sanyal AK, Uniyal VP, Chandra K, Bhardwaj M (2011). Diversity and indicator species of moth (Lepidoptera:Heterocera) assemblages in different vegetation zones in Gangotri Landscape, Western Himalaya. ENVIS Bulletin: Arthropods and their conservation in India (Insects \& Spiders) 14(1):116-132.

Schintlmeister A, Pinratana A (2007). Moths of Thailand. Brothers of St Gabriel in Thailand (Volume 5), Bangkok.

Smetacek P (2008). Moths recorded from different elevations in Nainital district, Kumaon Himalaya, India. Bionotes 10(1):5-15.

Smetacek P (2013). Review of Indian Lepidoptera Collections and their significance in conservation. ENVIS Bulletin: Arthropods and their conservation in India (Insects \& Spiders) 14(1):135-139.

Sondhi S, Sondhi Y, Roy P, Kunte K (2020). Moths of India. v. 2.00. Indian Foundation for Butterflies. Retrieved 2020 April 1 from http://www.mothsofindia.org/ 
Sondhi Y, Sondhi S (2016). A partial checklist of moths (Lepidoptera) of Dehradun, Mussoorie and Devalsari in Garhwal, $\begin{array}{lllll}\text { Uttarakhand, India. Journal of Threatened } & \text { Taxa }\end{array}$ https://doi.org/10.11609/jott.2814.8.5.8756-8776

Tan YQ, Dion E, Monteiro A (2018). Haze smoke impacts survival and development of butterflies. Scientific Reports 8:15667. https://doi.org/10.1038/s41598-018-34043-0

Theodorou P, Radzevičiūte R, Lentendu G, Kahnt B, Husemann M, Bleidorn C, ... Paxton RJ (2020). Urban areas as hotspots for bees and pollination but not a panacea for all insects. Nature Communications 11(1):576. https://doi.org/10.1038/s41467-020-14496-6

van Langevelde F, Ettema JA, Donners M, Wallis DeVries MF, Groenendijk D (2011). Effect of spectral composition of artificial light on the attraction of moths. Biological Conservation 144(9):2274-2281. https://doi.org/10.1016/j.biocon.2011.06.004

van Nieukerken EJ, Kaila L, Kitching IJ, Kristensen NP, Lees DC, Minet J, ... Zwick A (2011). Order Lepidoptera. In: Zhang Z-Q(Ed). Animal biodiversity: An outline of higher-level classification and survey of taxonomic richness. Zootaxa 3148:212-221.

Verma A, Kumar M, Bussmann R (2007). Medicinal plants in an urban environment: The medicinal flora of Banares Hindu University, Varanasi, Uttar Pradesh. Journal of Ethnobiology and Ethnomedicine 3:35. https://doi.org/10.1186/1746-4269-3-35

Verma P, Sagar R, Verma H, Verma P, Singh DK (2015). Changes in species composition, diversity and biomass of herbaceous plant traits due to $\mathrm{N}$ amendment in a dry tropical environment of India. Journal of Plant Ecology 8(3):321-332. https://doi.org/10.1093/jpe/rtu018

Wahlberg N, Wheat CW, Peña C (2013). Timing and patterns in the taxonomic diversification of Lepidoptera (butterflies and moths). Plos One 8(11):e80875. https://doi.org/10.1371/journal.pone.0080875

Young BE, Auer S, Ormes M, Rapacciuolo G, Schweitzer D, Sears N (2017). Are pollinating hawk moths declining in the Northeastern United States? An analysis of collection records. Plos One 12:e0185683. https://doi.org/10.1371/journal.pone.0185683

Zhu W, Yan J, Song J, You P (2018). The first mitochondrial genomes for Pyralinae (Pyralidae) and Glaphyriinae (Crambidae), with phylogenetic implications of Pyraloidea. Plos One 13(3):e0194672. https://doi.org/10.1371/journal.pone.0194672

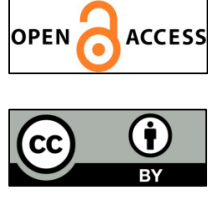

The journal offers free, immediate, and unrestricted access to peer-reviewed research and scholarly work. Users are allowed to read, download, copy, distribute, print, search, or link to the full texts of the articles, or use them for any other lawful purpose, without asking prior permission from the publisher or the author.

License - Articles published in Notulae Scientia Biologicae are Open-Access, distributed under the terms and conditions of the Creative Commons Attribution (CC BY 4.0) License.

(c) Articles by the authors; SHST, Cluj-Napoca, Romania. The journal allows the author(s) to hold the copyright/to retain publishing rights without restriction. 